\title{
Evaluation and Description of Factors that Affect Teachers Performance on Private High School in Indonesia
}

\author{
Nicolas Chally Tirayoh ${ }^{1} \quad$ Joulanda A.M Rawis $^{2}$ \\ 1.Post Graduate Student on Department of Education Management, Universitas Negeri Manado, Indonesia \\ 2.Senior Lecturer at Department of Education Management, Universitas Negeri Manado, Indonesia
}

\begin{abstract}
The purpose of this study to reveal the performance of the private high school teachers in Manado city which is investigated from the planning, the implementation, and the learning assessment, understanding their respective influence of the incentive, work environment, and infrastructure on the performance of teachers, and getting to know the influence of incentive, work environment, and infrastructure jointly on the performance of teachers. This study approach is utilizing quantitative with the ex post facto design. The population of this study is the private high school teachers in Manado city with the total number of teachers 376 people, and the sample size amounting of 31 people. The data collected show that for learning plan is categorized very high, presentation of the learning implementation is categorized high, and learning assesstment is also categorized high. There is a positive and significant influence of incentive for the performance. Further, There is significant influence of work environment on the performance. There is no significant influence of infrastructure on the performance. Incentive, work environment, and infrastructure together have no significant influence on the performance.
\end{abstract}

Keywords: a teacher performance, incentive, work environment, and infrastructure

DOI: $10.7176 / \mathrm{JEP} / 10-3-08$

\section{INTRODUCTION}

Efforts to improve learning achievement one of them is by improving teacher performance. Efforts of the principal to improve student achievement cannot directly but must go through teacher performance improvement (Fanani, Mardapi, \& Wuradji 2007, p2). Government efforts are also carried out by conducting performance assessments teacher in the framework of fostering and developing professional teachers conducted from teachers, by teachers, and for teachers. Assessment of teacher performance is related to the effectiveness of learning which covers various aspects, both relating to input, process, or output.

Teacher performance appraisal should be conducted periodically and evaluated by headmaster or teacher appointed by the principal to give a view regarding the performance $\mathrm{g}$ uru. Teacher performance assessment also used as a first step for knowing what factors influence teacher performance. Many factors can affect the performance of teachers, including k esejahteraan. Based on COMPASS information, 4 April 2008 that low welfare teacher $\mathrm{k}$ ar ar teacher salary is very limited so existing funds are only able to finance school for their children so the teacher doesn't able to continue education to a level higher. In addition, in terms of facilities and infrastructure shows that school private sector in remote areas only with minimal support, so for private teachers this case $m$ enghambat performance the teacher.

Other factors that affect performance teacher among others level of effort, eg motivation. Low teacher motivation make a teacher do not have work morale and do not have self-confidence, it is the duty of the principal to motivate the teachers in order to get better performance. The importance of motivating teachers in addition to improving teacher performance creates an atmosphere fun work and school. Head the school has a duty to motivate the teacher in working, maintaining harmony and communication between the principal and teacher or fellow teacher, in other words maintaining a working environment that is conducive. Limitation of this research problem namely the assessment of teacher performance in schools includes planning, implementation and learning assessment. Factors that affect teacher performance in this study limited to reward factors, work environment, and infrastructure.

\section{RESEARCH METHOD}

This type of research uses a quantitative approach with ex post facto design. This study aims to determine the performance of teachers and the factors that affect the performance of a high school teacher's private party in the city of Manado and determine the effect of variable free ie rewards, work environment, and facilities for teacher performance. This research was conducted in private high schools City of Manado, in January 2018 up to April 2018 , validation and instrument testing was carried out on the month December 2017 , field data collection is conducted from January to February, data processing is done in March, and writing results in April .

The results of this study were private high school teachers in the city of Manado which amounted to 376 teachers. Data samples were as much as 31 teachers from four private high schools namely Brother Don Bosco High School, Eben Heizar Christian High School, Pioneer School, and Pertiwi Sulut High School . Sampling technique the first is to use proportional cluster sampling based on the area of Manado City and the geographical 
location of Manado City can be divided into four parts namely north, center, east, and south. Technique the second sampling is proportional random sampling. Data collection is done with filling out questionnaires for both performance assessment instruments and system variable instruments compensation, work environment, and infrastructure.

The data in this study include 6 things namely, learning planning, implementation learning, and assessment of learning outcomes, factors reward, work environment factors. Instrument teacher performance appraisal using instruments questionnaire. Questionnaire for planning and assessment learning has the same format namely like self-assessment so that it fills up the questionnaire is the teacher. Besides the questionnaire planning and assessment of learning, the questionnaire for the implementation of learning also has the same scoring, namely with 4 categories, it's just that this questionnaire is filled out by the teacher appointed by the principal in the process his judgment. Variable questionnaire, work environment, and infrastructure facilities are filled by the teacher himself to gather information directly.

Proof of content validity obtained through rational analysis by experts on instruments (expert judgment) and using formulas Aiken's V to calculate content-validity coefficient. Expert judgment involves three experts from Sam Ratulangi University, the results of the examination showed that the instruments were suitable for use with several repair.

Estimated coefficient of reliability of the four variables, namely performance, compensation, work environment, and $\mathrm{s}$ arana infrastructure all said to be reliable when analyzed. Descriptive data analysis techniques are used to describe variables of teacher performance, rewards, work environment, and infrastructure. Correlational techniques are used to determine the magnitude of the influence of reward factors, work environment, and infrastructure on teacher performance.

The grouping of data categories is based on ideal averages as ideal comparison and standard deviation, which are then grouped into five categories. Formula for calculating averages ideal used formula:

$\mathrm{Mi}=1 / 2$ (highest ideal value + lowest ideal value) Whereas, SDi is calculated using the formula: $\mathrm{SDi}=1 / 5$ (highest ideal value-lowest ideal value)

The grouping as stated by Azwar (2015, 148-149) can be set as follows.

Table 1. Category of Assessment

\begin{tabular}{ccc}
\hline No & Skor & Kategori \\
\hline 1 & $\mathrm{X} \geq \mathrm{Mi}+1,5 \mathrm{Sdi}$ & Very Good \\
2 & $\mathrm{Mi}+0,5 \mathrm{Sdi} \leq \mathrm{X}<\mathrm{Mi}+1,5 \mathrm{Sdi}$ & Good \\
3 & $\mathrm{Mi}-0,5 \mathrm{Sdi} \leq \mathrm{X}<\mathrm{Mi}+0,5 \mathrm{Sdi}$ & Acceptable \\
4 & $\mathrm{Mi}-1,5 \mathrm{Sdi} \leq \mathrm{X}<\mathrm{Mi}-0,5 \mathrm{Sdi}$ & Poor \\
5 & $\mathrm{X}<\mathrm{Mi}-1,5 \mathrm{Sdi}$ & Very Poor \\
\hline
\end{tabular}

Information:

Mi: average overall score

Sdi: standard deviation of the overall score

$\mathrm{X}$ : score achieved

The data that has been categorized is then described and interpreted for each research variable.

\section{RESEARCH RESULT}

The results of private high school teacher learning planning analysis in Manado City according to the teacher's perception is very good $61.3 \%$, both $32.3 \%$, and moderate $6.5 \%$. Whereas obtained mean or average score of 34.16 which lies in the interval score $\geq 34$ in very good category. Thus the private high school teacher lesson plans in Manado City is said to be very good.

Implementation of high school teacher learning the private sector in Manado City is said to be good. Implementation of private high school teacher learning in City of Manado according to teacher perceptions that is very good $6.5 \%$, both $48.4 \%$, and medium $45.1 \%$. Whereas obtained mean or score an average of 69.58 which lies in the interval score of $67.2-81.5$ in the good category.

Assessment of high school teacher learning private sector in the city of Manado according to teacher perceptions that is very good $38.7 \%$, both $48.4 \%$, and currently $12.9 \%$. Whereas the mean is obtained or an average score of 32.23 located in the interval score 28-33 in the good category. Thus the assessment of teacher learning Private high school in the city of Manado said well.

The reward factor for private high school teachers is at City of Manado according to teacher perceptions that is very good $6.4 \%$, both $13 \%$, and medium $38.7 \%$, quite good $32.2 \%$, and not good $9.7 \%$. Whereas obtained mean or score an average of 25.45 located at interval score 24-30 in the medium category. Thus the assessment of teacher learning Private high school in the city of Manado said is being Factors of private high school work environment in the city of Manado according to teacher perceptions which is very good $87 \%$ and good $13 \%$. Whereas obtained mean or average score equal to 74,74 which lies in the score interval $\geq 68$ in the very good category. Therefore the private high school working environment in the city of Manado is said to be very good. 
Infrastructure facilities for private high schools in the city of Manado according to teacher perceptions respectively $38.7 \%$, while $48.4 \%$, and $12.9 \%$ good enough. Whereas obtained mean or average score of 52.23 which is in the interval score 44 - 55 in the medium category. Thus infrastructure Private high school in the city of Manado said is moderate/ acceptable.

Test requirements for analysis have met all assumptions that are prerequisites for analysis that there is no assumption of normality, heteroscedasticity, autocorrelation, and multicollinearity between independent variables in the regression model.

\subsection{Effect of Rewards on the Performance of Private High School Teachers in Manado City}

Test the magnitude of the effect of rewards the teacher's performance is partially used simple linear regression. Before determining the magnitude of the effect of reward variables is addressed teacher performance, it will be analyzed first about the closeness of the relationship between two variables that is. Based on computer output regarding the correlation coefficient, a correlation coefficient of 0.409 was obtained and this coefficient was marked positive. This shows that if the reward increases or is good, the teacher's performance will increase also. From the results of Table 2 it is concluded that Ho is refused to test the significance of constants and $\beta 1$ coefficient which means that the independent variable X1 has a linear relationship with dependent variable Y. The results of the $t$ test based on computer output can be seen in Table 2 .

Table 2. T-Test Results for Rewards Variables

\begin{tabular}{|c|c|c|c|c|c|}
\hline \multicolumn{6}{|c|}{ Coeficients $^{\mathrm{a}}$} \\
\hline \multirow[t]{2}{*}{ Model } & Unstand & oefficient & \multirow{2}{*}{$\begin{array}{c}\text { Standardized Coefficient } \\
\text { B }\end{array}$} & \multirow[t]{2}{*}{$\mathrm{T}$} & \multirow[t]{2}{*}{ Sig } \\
\hline & B & Std.Error & & & \\
\hline$(\text { constant })^{1}$ & 114.900 & 8.981 & & 12.793 & .000 \\
\hline Faktor $^{1}$ & .721 & .299 & .409 & 2.414 & .002 \\
\hline
\end{tabular}

Table 3. Results of Anova Rewards Variables

\begin{tabular}{|c|c|c|c|c|c|}
\hline \multicolumn{6}{|c|}{ Coeficients $^{\mathrm{a}}$} \\
\hline${ }^{1}$ Regression & 817.626 & 1 & 817.626 & 5.830 & $.022^{\mathrm{a}}$ \\
\hline Residual & 4067.342 & 29 & 140.253 & & \\
\hline Total & 4884.968 & 30 & & & \\
\hline
\end{tabular}

A and the magnitude of the effect of rewards the performance of the teacher can be seen in Table 4. Table 4. R Square Table

$\begin{array}{ccccc}\text { Model } & \mathrm{R} & \mathrm{R} \text { Square } & \text { Model Summary } \\ 1 & .409^{\mathrm{a}} & .167 & .139 & \text { Stjusted R Square } \\ & & .167 \text {. Eror Of The Estimate }\end{array}$

Based on the output obtained regression coefficient of 0.409 , then form regression equation $\mathrm{Y}=0.409 \mathrm{X} 1$. This means that if the reward increases by 1 point then teacher performance will increase by 0.409 points. In other words, the better im balan then the teacher's performance will increase. This relationship is also linear, this is explained with the F test results through the sig computer output $0.022<0.05$. This can be said also the model regression is a model that can estimate teacher performance is a positive and significant influence. The positive and significant influence of reward variables on teacher performance can be seen in Table 3 .

Based on Table 4 can be explained that the $\mathrm{R}$ square value is 0.167 . This means that the variable rewards affect teacher performance by $16.7 \%$ and the remaining $83.3 \%$ is determined by other reasons outside the regression model. Effect of Work Environment on Performance Private High School Teacher in Manado City Test the magnitude of environmental influences work on teacher performance partially used simple linear regression. Before determining the effect of variable b esarnya work environment on the performance of teachers, it will analyzed first about closeness relationship between these two variables. Based on computer output regarding correlation coefficients, obtained a correlation coefficient of 0.412 and this coefficient is positive. This shows if the work environment is good then performance the teacher will increase. From the results of Table 5 it can be concluded that Ho is rejected for the significance test the constants and coefficients $\beta 2$, which means the independent variable X2 has a linear relationship with the dependent variable $\mathrm{Y}$. The results $\mathrm{t}$ test based on computer output can be seen in Table 5 .

Based on the output obtained regression coefficient of 0.412 , then form regression equation $\mathrm{Y}=0.412 \mathrm{X} 2$. This means that if the work environment increases by 1 points, the teacher's performance will increase by 0.412 points. In other words, the more good work environment so the teacher's performance will increase. This relationship is also linear, this is explained by the results of the $\mathrm{F}$ test through output computer sig $0.021<0.05$. This can be said also the regression model is a model that can estimating the teacher's performance, namely its influence positive and significant. Positive and significant working environment variables towards Teacher 
performance can be seen in Table 6 .

Table 5. Environmental Variable T Test Results Work

\begin{tabular}{cccccc}
\hline & \multicolumn{5}{c}{ Coeficients $^{\mathrm{a}}$} \\
& $\mathrm{B}$ & Std. Error & Beta & Sig \\
1 (Constant) & 73.924 & 25.587 & & 2.889 & .007 \\
Faktor 2 & .830 & .341 & .412 & 2.433 & .021
\end{tabular}

Table 6. Environmental Variable Anova Results Work

\begin{tabular}{|c|c|c|c|c|c|}
\hline \multicolumn{6}{|c|}{ ANOVA $^{b}$} \\
\hline Model & Sum of Squares & Df & Mean Squares & $\mathrm{F}$ & Sig. \\
\hline 1 Regression & 828.238 & 1 & 828.238 & 5.921 & $.021^{\mathrm{a}}$ \\
\hline Residual & 4056.729 & 29 & 139.887 & & \\
\hline Total & 4884.968 & 30 & & & \\
\hline
\end{tabular}

The magnitude of the influence of the work environment on teacher performance can be seen in Table 7 . Table 7. Table R square

$\begin{array}{ccccc}\text { Model } & \mathrm{R} & \text { R Square } & \begin{array}{c}\text { Model Summary } \\ \text { Adjusted R Square }\end{array} & \text { Std. Error Of The Estimate } \\ 1 & .412^{\mathrm{a}} & .170 & .141 & 11.82739\end{array}$

Based on Table 7 it can be explained that the $\mathrm{R}$ square value obtained is 0.170 . This means that the work environment variable affect teacher performance by $17.0 \%$ and the remaining $83.0 \%$ is determined by other reasons outside the regression model.

\subsection{Effect of Infrastructure on the Performance of Private High School Teachers in the City of Manado} Testing the magnitude of the influence of infrastructure on teacher performance is partially used simple linear regression. Before determining the magnitude of the influence of the variable means infrastructure on teacher performance, it will analyzed first about closeness relationship between these two variables. Based on computer output regarding correlation coefficients, obtained a correlation coefficient of 0.332 and this coefficient is positive. This shows that if the infrastructure is good then the teacher's performance will increase. From the results of Table 8 it is concluded that Ho is accepted for the significance test $\beta 3$ coefficient which means independent variable X3 has a nonlinear relationship with dependent variable $\mathrm{Y}$ ( $\operatorname{sig} 0.068>0.05$ ). As for $t$ test results based on computer output can seen in Table 8 .

Table 8. T-Test Results for Infrastructure Variables

\begin{tabular}{cccccc}
\hline & \multicolumn{2}{c}{ Coeficients $^{\text {a }}$} \\
Model & Bnstandardized Coefficient & Standardized Coefficient & & \\
B & Std.Error & Beta & Sig. \\
\hline (constant) $^{1}$ & 98.306 & 20.013 & & 4.912 & .000 \\
\hline Faktor $^{3}$ & .721 & .381 & .332 & 1.893 & .068 \\
\hline
\end{tabular}

\subsection{Effect of Rewards, Work Environment, and Infrastructure on the Performance of Private High School} Teachers in the City of Manado

Test the amount of influence jointly in the reward system, work environment, and infrastructure facilities on the performance of teachers used multiple linear regression analysis. Based on the output in Table 9 the regression equation is obtained multiple linear ie $\mathrm{Y}=0.247 \mathrm{X} 1+0.256 \mathrm{X} 2+0.227 \mathrm{X} 3$. Positive regression line equation indicates that the third is better variable, the teacher's performance is getting better.

Table 9. T test results for variables X1, X2 and X3

\begin{tabular}{|c|c|c|c|c|c|}
\hline \multicolumn{6}{|c|}{ Coeficients $^{\mathrm{a}}$} \\
\hline & Unst & Coefficient & Standardized Coefficient & & \\
\hline Model & $\mathrm{B}$ & Std.Error & Beta & $\mathrm{T}$ & Sig. \\
\hline$(\text { constant })^{1}$ & 5.873 & 28.654 & & 2.055 & .050 \\
\hline Faktor $^{1}$ & .436 & .324 & .247 & 1.347 & .189 \\
\hline Faktor $^{2}$ & .517 & .369 & .256 & 1.399 & .173 \\
\hline Faktor $^{3}$ & .493 & .366 & .227 & 1.347 & .189 \\
\hline
\end{tabular}

As for the influence of variable X1, X2 and X3 on teacher performance together are presented in Table 10. 
Table 10. Anova tables for variables X1, X2, and X3

$\begin{array}{cccccc} & & & & \\ \text { Model } & \text { Sum of Squares } & \text { Df } & \text { Mean Squares } & \text { F } & \text { Sig. } \\ 1 \text { Regression } & 1377.224 & 3 & 459.075 & 3.534 & .028^{\text {a }} \\ \text { Residual } & 3507.744 & 27 & 129.916 & & \\ \text { Total } & 4884.968 & 30 & & & \end{array}$

If we see the partial test results in Table 10 for significance values factor 1 , factor 2 and all factors $3>\operatorname{sig}$ 0.05 so that all factors are not significant. The conclusion is that the reward system, work environment, and infrastructure facilities together have no significant effect on teacher performance

\subsection{Effect of Rewards on the Performance of Private High School Teachers in Manado City .}

The results of the descriptive analysis show that the performance of private high school teachers in Manado City is included in the high category, namely obtained an average value of 135.97. Value the average learning plan is equal to 34.16 is included in the very high category, then the average value of learning implementation at 69.58 this is included in the high category, and the average value of learning assessment amounting to 32.23 is included in the category high.

The performance of private high school teachers in Manado City is included in the category this high there are several factors that need to be noticed. Based on the results of descriptive analysis of the data it is known that high school teacher rewards private sector in Manado City is interpreted in the medium category. But from the data the researcher obtained perceptual data because the unit of analysis is different, this reward filled by the teacher while the reward is owned by school. If you look at the condition of the private high school in Manado City there are in urban and rural areas. Could It is said that both of them have gaps in various aspects. Private schools are schools that are not managed by the government. The point is that these schools are not funded by the government, overall or some of the funds are from donations students. The phenomenon of private schools in the countryside not as good as a private school in urban areas.

The number of students is not as much as in urban areas. The reward factor obtained between teachers in rural private schools are different with that in urban areas due to pay teacher $\mathrm{d}$ iperoleh of student donations. Based on the results of data analysis it is known that rewards have a significant effect on teacher performance. Analysis results too shows that the higher the reward, will result in high teacher performance, so that it can be said that rewards make a positive contribution to performance teacher. Based on data from research studies relevant there is research conducted by (Syahalam, Nugroho, \& Nasution, 2014) showed that rewards contributed $4.1 \%$ to the performance of lecturers certification in carrying out the learning process teaching at Bengkulu Health Ministry Polytechnic.

According to (Wagiran, Soenarto, \& Soedarsono, 2013) that rewards are influential direct or indirect towards the performance of the Technical Expertise Vocational School teacher Machine. In addition, the benefits received by the teacher of the foundation is not only salary but giving training or training through seminars, guidance of the school principal related to His expertise is included in the system reward. According to Sugiyono (2004) coaching headmaster, work motivation, and experience training has a significant and giving effect large influence on teacher performance in Bangkalan Madura District, then it can be said that this reward affect teacher performance

\section{DISCUSSION}

\subsection{Influence of the Work Environment on Private High School Teacher Performance in Manado City}

The performance of private high school teachers in Manado City is included in the category high, but there are several factors that can affect teacher performance in addition to rewards as described above, namely work environment factors. Based on the results of descriptive analysis of the data it is known that the environment private high school work in the city of Manado interpreted in very high categories. However, from the data that the researcher obtained from the perception data because the analysis unit was different, this reward was filled by the teacher whereas rewards are owned by the school. Nevertheless it can be said that private high schools are in The city of Manado has circumstances or the relationship between the teacher and the workplace very good. Based on the results of data analysis it is known that the work environment is influential significantly on teacher performance. A good work environment can be created through the supervision of the principal so that the teacher work harder. The working atmosphere created familial, good treatment interguru, feeling safe and comfortable in the environment work, as well as fair and wise treatment by the principal.

Based on data from relevant research, there are similar studies which are those which are conducted by Handayani (2005) which measures the influence of the level of education, infrastructure, and work environment on performance teacher at SMA N 1 Karangdowo. His research results show that the work environment has a significant influence on teacher performance in SMA N 1 Karangdowo. Besides it was a research conducted by Ristiana (2012) show that simultaneously the work environment has a positive and significant effect on the 
performance of GTT in the Regency Holy. M ccording Suarta (2012) found a significant effect on the learning environment and provide a contribution of $14 \%$ of the students' skills, as well as the working environment of teachers it can be said that teacher's work environment has an effect on teacher performance. Then obey Wagiran, Soenarto, \& Soedarsono (2013) that principals' leadership has a significant effect on teacher performance, this brings understanding that head leadership High schools have an influence good for the work environment. Therefore it can be said that the working environment is both will influence the performance of the teacher good too.

\subsection{Effect of Infrastructure on Private High School Teacher Performance in Manado City}

Infrastructure factors have been many researched by education experts in relation these factors affect performance, especially teachers. Based on data from relevant research studies conducted by Tsalistiani (2011) showed that the facilities and infrastructure in Banjarnegara d SMAN high ikategorikan and the amount of contribution is as big as $14.4 \%$ of teacher performance. In addition, research conducted by Djatmiko (2006) infrastructure influences performance Semarang City Middle School teachers as big as 36.9\%. In this study, facilities and infrastructure in Manado City Private High School categorized as being. In Ministerial Regulation RI National Education number 24 in 2007 section IV about the standards of facilities and infrastructure for SMA / MA. Feasibility of facilities and infrastructure to support learning activities has been described in the Permen.

What is the feasibility of building area, land, complete facilities and infrastructure such as space class, library room, laboratory room, leadership room, teacher's room, administration room, places of worship, and so on. Means conditions facilities and infrastructure Private High Schools in Manado City have complied with the Regulations Minister of National Education of the Republic of Indonesia number 24 in 2007.

In this study researchers obtained data that facilities and infrastructure do not significantly influence performance Private high school teacher in Manado City. Thing this is caused by the data that the researcher obtained in the field it shows a lack of diversity the results of answers from respondents in this matter the results reveal that the facilities infrastructure in private high schools in Manado City is feasible and can still be used inside learning.

\subsection{Effects of Rewards, Work Environment and Infrastructure on the Performance of Private High School Teachers in the City of Manado}

Based on the results of multiple regression analysis, the regression line equation is obtained $\mathrm{Y}=0.247 \mathrm{X} 1+$ $0.256 \mathrm{X} 2+0.227 \mathrm{X} 3$. This result show this positive sign accordingly with theory and can be interpreted as rewards, work environment, and infrastructure well then the teacher's performance will be increasingly well. The results of the regression line equation can also be interpreted if the variable is reward one point increases, the teacher's performance will increased by 0.247 . If the work environment one point increases, the teacher's performance will increased by 0.256 and if infrastructure increased by one point then teacher performance will increase by 0.227 .

According to the results of the regression analysis then for significance values of factors 1 , factors, and factor 3 is greater than sig 0.05 so all factors are not significant. The conclusion is that rewards, work environment, and infrastructure facilities together have no significant effect on teacher performance. This is caused by data obtained less diverse both it's variable data rewards, work environment, and infrastructure. Besides it's the limitation of the reward system instrument used also for environmental factors work and reward. When tested simultaneously shows insignificant results this is caused by the data generated perceptual. The same is assessed by Different respondents and different results are called perceptions.

\subsection{Research Limitations}

The implementation of this research has been made to the maximum extent possible to fit with the aim of research, but still exists limitations and weaknesses that are not avoided include the following. First, this research has not been comprehensive in its description because limited data collection only comes from data headmaster and teacher, haven't taken it data from students as users. Second, data obtained by the researcher is perception data, where the same item is valued by different respondents, the results are different then it is called perception. Third, the unit of analysis from this research is a teacher but in the process Researchers ratings $\mathrm{m}$ enggunakan variable factors influencing the performance of teachers school analysis unit, this raises data perception. Fourth, data collection in This research was based on the results of questionnaire entries by Private high school teacher and questionnaire by the Head Schools, so that there is a possibility of the variety of results of respondents' answers in the filling process. Fifth, it is difficult to obtain permission from a school that is used as a place of research for various reasons teacher's busy life. Sixth, the factors that are affect teacher performance very much, but in this study only revealed three variables studied are the reward system, work environment, and infrastructure. Thing it only expresses in line the magnitude, therefore there needs to be other studies involving factors others that affect teacher performance outside these three factors. 


\section{CONCLUSIONS AND SUGGESTIONS \\ 5.1 CONCLUSIONS}

Based on the results of the analysis and discussion the conclusions can be drawn as follows. First, the performance of private high school teachers in Manado City is relatively high, this can be seen from the collected data that for learning planning is categorized very well with a percentage of $61.3 \%$, implementation learning is categorized as good with a percentage of $48.4 \%$, and learning assessment is categorized as good with a percentage of $48.4 \%$. Second, there are positive and significant influences rewards for the performance of private high school teachers in Manado City with coefficient values regression of 0.409 , the significance level 0.022 and the amount of the contribution to teacher performance is $16.7 \%$. Third, there are positive influences and significant work environment towards performance Private high school teacher in Manado City with a regression coefficient of 0.412 and the significance level is 0.021 and the amount of the contribution to the teacher's performance is obtained by $17 \%$. Fourth, there is no influence a significant means of infrastructure on the performance of private high school teachers in the city of Manado is because of the data obtained is perception and answer data respondents are less varied. Fifth, reward, work environment, and infrastructure facilities together have no significant effect on the performance of private high school teachers in the city of Manado this is caused by perception data, where rewards, work environment, and facilities this infrastructure belongs to the school assessed by the teacher the result is not significant this is perception.

\section{Implications}

This research is intended to know teacher performance and factors affect the performance of private high school teachers in Manado City . It is expected that the results of this study can provide and improve the performance of private high school teachers in the city of Manado. Work environment factors provide the most significant effect on the performance of private high school teachers in the city of Manado. This has implications for enthusiasm and work productivity, if you want the performance of private high school teachers to increase then efforts are needed to pay attention work environment factors. Working environment conducive will make teachers more active for work or in other words you will improve teacher performance.

\subsection{Suggestions}

Based on the results of research on the performance of private high school teachers in the city of Manado and the influencing factors, here are some suggestions, between others: (1) based on the results of the research known that the reward factor and work environment significantly influence performance teacher, therefore high school principal the private sector in Manado City needs to pay attention to these factors so that the teacher's performance can be improved; (2) for school principals and the leadership of the foundation should pay attention private high school teachers who have performance well. An evaluation of performance is needed teacher every year on an ongoing basis, so that the evaluation data can be made guidelines for holding promotions or recommendations for both job proposals and salary increases .

\section{REFFERENCES}

Azwar, S (2012). Penyusunan skala psikologi edisi 2.Yogyakarta: Pustaka Pelajar.

Djatmiko, E. (2006). Pengaruh kepemimpinan kepala sekolah dan sarana prasarana terhadap kinerja guru smp negeri kota semarang. Jurnal Fokus Ekonomi, Vol 1 No 2, 19-30.

Handayani, Bekti (2005). Pengaruh pendidikan, sarana prasarana, dan lingkungan kerja terhadap kinerja guru di SMA Negeri 1 Karangdowo. Tesis Magister, tidak diterbitkan, Universitas Muhammadiyah Surakarta.Surakarta.

Fanani, Z., Mardapi, D., \& Wuradji, W. (2014). Model asesmen kepemimpinan pembelajaran kepala sekolah pendidikan dasar.Jurnal Penelitian dan Evaluasi Pendidikan, 18(1), 129-145. Retrieved from http://journal.uny.ac.id/index.php/jpep/article/view/2129

Mendikbud. (2007). Peraturan Menteri Pendidikan Nasional Republik Indonesia Nomor 24, Tahun 2007, tentang Standar Sarana dan Prasarana untuk Sekolah Dasar/Madrasah Ibtidaiyah (SD/MI), Sekolah Menengah Pertama/Madrasah Tsanawiyah (SMP/MTs), dan Sekolah Menengah Atas/Madrasah Aliyah (SMA/MA).

Ristiana, N. (2012). Pengaruh kompensasi, lingkungan kerja, dan motivasi kerja terhadap kinerja guru tidak tetap (GTT). Skripsi sarjana, tidak diterbitkan, Universitas Diponegoro. Semarang.

Suarta, I. (2013). Hubungan sistem pembelajaran, lingkungan belajar, konsep diri dan pengembangan employability skills mahasiswa. Jurnal Penelitian dan Evaluasi Pendidikan, 16, 24-41. Retrieve fromhttp://journal.uny.ac.id/index.php/jpep/article/view/1104

Sugiyono, S. (2004). Pengaruh Pembinaan Kepala Sekolah, Motivasi Kerja, dan Pengalaman Diklat terhadap Kinerja Guru dalam Pembelajaran Bahasa Madura di SDN Kecamatan Bangkalan Kabupaten Bangkalan Madura. Jurnal Penelitian dan Evaluasi Pendidikan, 6(1). Retrieved from http://journal.uny.ac.id/index.php/jpep/ article/view/2044

Syahalam, E., Nugroho, S., \& Nasution, N. (2014). Pengaruh motivasi kerja, kepuasan kerja, imbalan terhadap 
kinerja dosen sertifikasi dalam melaksanakan proses belajar mengajar dipoltekkes kemenkes bengkulu tahun akademik 2012/2013. The Manager Review Jurnal Ilmiah Manajemen, 15 (3). pp. 560-570. ISSN $1979-2239$

Tsalistiani, H. 2011. Asesemen kinerja guru non-PNS di SMAN Kabupaten Banjarnegara dan faktor-faktor yang mempengaruhinya. Tesis Magister, tidak diterbitkan, Universitas Negeri Yogyakarta, Yogyakarta.

Wagiran, W., Soenarto, S., \& Soedarsono, F.(2013). Determinan kinerja guru SMK bidang keahlian teknik mesin. Jurnal Penelitian dan Evaluasi Pendidikan, 17(1), 148-171. Retrieved from http://journal.uny.ac.id/index.php/jpep 